\title{
Restoring childhood: humanitarianism and growing up Syrian in
} Za`tari refugee camp

\author{
Melissa N. Gatter
}

Middle Eastern Studies, University of Cambridge, Cambridge, UK

Trinity Hall College, Trinity Lane, Cambridge CB2 1TJ, UK | +07392 921627 mg745@cam.ac.uk | @melgatter (Twitter)

Melissa Gatter is a PhD student at the University of Cambridge who examines questions of identity and humanitarianism in spaces of displacement in the Middle East. 


\title{
Restoring childhood: humanitarianism and growing up Syrian in Za` tari refugee camp
}

\author{
Of the 80,000 Syrians living in Za'tari refugee camp in Jordan, roughly 44,000 \\ are under the age of eighteen. This article explores childhoods lived in \\ displacement in this humanitarian space. Za'tari's humanitarian apparatus \\ believes children have lost their childhood due to past trauma from the war and \\ current displacement in a refugee camp. Based on ethnographic fieldwork, the \\ article explores the ways in which NGOs aim to 'restore' these lost childhoods by \\ promoting youth, enabling agency, and refocusing children's attention on their \\ future return to Syria. Through interactions with aid workers during \\ programming in child-friendly spaces, children learn new skills, expand social \\ circles, and develop forward-looking goals. Children are also active navigators of \\ life in the camp. I argue that by customizing childhoods cultivated in child- \\ friendly centres to their individual circumstances, children construct a Syrian \\ identity that is more complex than the apolitical Syrianness encouraged by NGOs \\ and inherently different from one that would have been cultivated in Syria. \\ Against humanitarian discourses of a lost Syrian generation, my material sheds \\ light on a nuanced (rather than lost) generation that is basing its identity on \\ experiences in $\mathrm{Za}$ tari as well as on the idea of return to and reconstruction of \\ Dar`a, its home city.
}

Keywords: refugees; children; refugee camp; humanitarianism; Jordan; Syria; Za`tari, Dar`a

Driving through Za tari refugee camp in Mafraq, Jordan, one observes the overwhelming presence of children. Young boys and girls walk with siblings or friends in the market and carry bright backpacks that seem oversized in comparison to the wearer. Women clad in long black dresses prop babies up on their hips while shopping for toys or clothes. Teenage boys walk with their arms slung around their friends, and others carry merchandise or children on their bikes. In Za'tari's less crowded residential areas, children can be seen playing soccer, exploring the sandy areas around their homes, swinging on dead wires hanging from electrical poles, carrying or bullying younger siblings, flying kites, and driving donkey-led carts of produce. Very young children can be seen in various states of dress, hanging out by small water tanks, and throwing rocks at passing vehicles. Extremely dry skin and sandy faces are common side effects for active children playing in the dry wind, but they never seem particularly concerned or bothered by this.

Some 44,000 Za tari residents, a little more than half of the population, are under the age of eighteen. About 16,000 of those children are four years old or younger, having been born in the camp or brought to it quite young (UNHCR 2017). It is common for children to be involved in NGO activities, whether for schooling, psychosocial programming, recreation and sports, or skills training. This study closely examines interactions between humanitarian aid workers and children-those whose memories of Syria are weak and those who spent most of their childhoods in Syria- to analyze how both parties navigate childhood in the refugee camp.

Feldman's $(2008,2012)$ study of humanitarianism in Gaza and the Gazan diaspora in Jordan illuminates this article's conceptualization of the situation of Syrians in Za tari. She describes the Jerash camp for Gazan Palestinians in Jordan as existing in a humanitarian 'condition' (2012, p. 160) rather than a 'crisis'. In long-term displacement, she writes, camp residents do not need immediate saving. Nor can their 
lives be improved in the time being (Feldman 2015). While the ongoing conflict in Syria may constitute a humanitarian crisis, the lives of Za'tari's residents are governed by a humanitarian power that has been in place for five years and treats the situation as ongoing until future return to Syria can be granted, at which point its services would no longer be needed.

In general, humanitarianism approaches the child as an 'incomplete and innocent' being who is inherently 'in need' (Quaretta 2016, p. 100). Children's welfare and identity are tied to place (Jack 2010), which humanitarianism believes should ideally revolve around the home, school, and safe spaces for play. For example, Palestinian families living in an environment of daily political violence in Israel considered the physical home to be central to the healthy development of their children (Akesson 2014). The aspects of family, learning, and play form the 'pillars of childhood' (Olujic 1998, p. 323), their collapse implying the destruction of a healthy childhood environment. Humanitarianism's emphasis on place in childhood puts children in displacement in a greater state of exception, 'out of place' (Connolly and Ennew 1996, p. 133) or in an unwieldy category such as 'Children in Especially Difficult Circumstances' (UNICEF 2016). The humanitarian world, therefore, perceives children who have fled violence or were born into statelessness as having experienced a loss of childhood and innocence (Poretti et al 2014, Suski 2009). Consequently, the focus of NGO programming for children aims to restore childhood by rebuilding these 'pillars of childhood' and recreating a sense of normality.

Before it was a refugee camp, Za'tari was a plot of empty land next to a Jordanian village of the same name. Preparing the land for a population of refugees meant the development of 'virgin territory' (Agier 2011, p. 201) and the installation of infrastructure on a physical space that humanitarians suppose contains no prior history. Humanitarian perception of Za tari as a blank slate extends to the camp's residents as well. They are treated as citizen-less and identity-less, merely because they dwell in that space. Children in Za tari are confronted with the reality of this humanitarian governance, which has replaced the Syrian state in providing services that inevitably shape childhood, with new customs and conditions. Apart from being an apparatus, humanitarianism in Za 'tari is an order, indeed the order of things in the camp. Za 'tari's humanitarian administration, supported with security from the Jordanian government, governs over the camp as a sovereign. Papers are required for entering and exiting the camp through a designated gateway. Its invisible borders mark a humanitarian space designated for a specific population. NGOs provide services such as education, healthcare, and family support that would otherwise be the responsibility of a state government.

This article explores the production of childhood within this humanitarian condition. How does humanitarianism believe it is providing children with a restored youth, and how do children respond to these efforts? What possibilities are created out of interactions between NGOs and children? In a state of protracted temporariness, how does the humanitarian apparatus address time, and especially the future, for the camp's children? Literature on humanitarianism is lacking in studies on small-scale activity, or the 'politics of living' (Feldman 2012, p. 157), in humanitarian space. This study relies on observations of daily activity of children in Za tari - their routines, hobbies, and interactions with NGOs - to get closer to an understanding of the politics of living as a child in ongoing displacement in Za tari refugee camp.

It is important to note that the normal and abnormal in spaces of crisis are not clear-cut. Other scholars have questioned this dichotomy. Kelly's (2008) exploration of the blurred lines between norm and exception in his ethnography of mundane life during 
the second Palestinian Intifada problematizes anthropological understandings of normal and abnormal. Jansen (2014) analyses the paradox of normality as an aspiration for people living in post-socialist Sarajevo who view normal lives as something stuck in their past. Navaro-Yashin (2003) urges anthropologists to not take normality for granted in extended emergencies but to complicate it as pretence. For many children living in Za tari, camp life has become the norm. Yet, humanitarianism works to alleviate what it considers to be abnormal for children in displacement. My argument is that Za'tari's humanitarian apparatus manages and 'restores' childhoods by adjusting the ongoing present (displacement in Za tari) to make up for the past (lost childhood in Syria) and prepare for the future (rebuilding Syria). In an attempt to create the conditions for a perceived appropriate childhood in abnormal circumstances, NGO programming promotes youth, enables agency, and refocuses children's attention away from their political histories toward their futures in Syria. Through interactions with aid workers during programming in child-friendly spaces, children learn new skills, expand social circles, and develop forward-looking goals. Children still must deal with what humanitarians consider abnormalities of displacement: particularly child labour and early marriage challenge humanitarian efforts to restore childhood. But as this article will demonstrate, children prove to be active agents in the navigation of life in the camp, customizing humanitarian cultivation of childhood to their individual circumstances. An essential part of NGO programming's attempts to restore childhood entails the promotion of an abstract and apolitical idea of return to Syria. However, as I will show, children continue to express a more complex Syrian identity contingent on the return to specific places, times, and people in Dar`a. The picture presented below asserts that humanitarian efforts to restore childhood in the camp have created a nuanced - not a lost - Syrian generation, one whose identity is shaped by experiences in Za tari and motivated by the idea of return to and the reconstruction of Dar'a.

This article begins by examining the work completed by humanitarians in Za tari in the ongoing present. My material captures the daily actions that aim to foster placemaking, socialization, agency, and learning within NGO child-friendly centres. It explores how children respond to these projects and adapt intangible benefits and tangible skills to their individual situations. The article then discusses the specific future that NGOs promote and the ways it contrasts with the futures envisioned by the children. Through an analysis of children's dreams for their future, my aim is to show how children in Za tari are forming a new Syrian identity through their engagement in both the humanitarian network and their memories of home in their new home.

\section{Researching Childhood}

Fieldwork for this project was completed in Za tari refugee camp in Jordan during February and March 2016. Access to Za tari was secured through an internship with the Media, Communications, and Advocacy department of the organization Save the Children, whose main offices are located in Amman, Jordan. Data was collected through ongoing informal conversations with children between the ages of three and nineteen at various Save the Children centres in Za tari and through focused case study interviews with ten children and adults of various ages. All material appearing in this article was obtained after verbal informed consent.

Completing fieldwork through an organization somewhat limited the questions posed to refugees. However, this position also benefited the research in that it established a level of trust with my research participants and minimized scepticism that is usually pointed toward journalists or other non-humanitarian outsiders. Interactions 
with individuals felt comfortable and conversations were quite candid and natural. Additionally, being female made possible friendships with female refugees that are generally off-limits for male aid workers and ethnographers, and I often became the designated advocate for girls during visits by outside filmmakers and photographers.

I acknowledge that this article cannot offer a comprehensive view of children in Za'tari refugee camp. Interactions with children who did not attend NGO child-friendly centres were minimal. Further research is needed to learn more about the situation of those children who choose not to be involved in NGO programming. This project also did not have access to the camp's religious networks, though many children openly expressed the priority religion has in their lives, and thus does not consider religion's role in shaping their childhood in displacement.

Throughout the article, I use the term 'child' as it is defined by NGO programming to refer to camp residents between the ages of one and nineteen. This research emphasizes that while societies in general tend to dismiss children as inferior to adults and keep them separated from adult socialization (Wyness in Quaretta 2016, p. 100), children must be considered important agents in shaping their own lives as well as their communities. Aware of the overall absence of children's voices in humanitarian literature, fieldwork for this project made an effort to find creative ways to speak with children and let them lead conversation.

\section{Childhood from Dar`a to Za`tari}

In the Middle East, as in other places, the child embodies the continuation of a generation into the future (Fernea 1995, p. 4). The role of the child as a temporal connector has become key in the Syrian conflict. It was children who played the preliminary role in Dar'a's rebellion against the Syrian state and thus became symbolic figures in the ensuing struggle against Assad. In March 2011, fifteen children in the south-western region of Dar`a were arrested for anti-regime graffiti written on their school wall. The arrest sparked protests by the community that was outraged by the inhumane torture of children. Anger in Dar`a became even more intense when a thirteen-year-old boy died in custody a few months later (Wedeen 2013, p. 855). Protestors began to rally 'around the innocence and hopes of children, as if contrasting their own cause with that of a savage regime already propelled into the past' (Leenders 2013 , p. 255). In addition to the absence of a public outlet for expressing dissatisfaction with the regime, protesters saw their struggle embodied in children: they envisioned Syrian children as emblematic of a better future for Syria, one that is not yet realized and must be fought for.

Scholars of Syria have argued that even in the years leading up to the protests, those frustrated with the regime had begun to look to children as representatives of an uncomplicated and inclusive Syrian identity in the face of Assad's increasingly selective ideology. Since his assumption as president in 2000, Assad's cosmopolitan lifestyle had implied promises for 'the good life' (Wedeen 2013, p. 855) that never came to be realized in Syria's provincial areas. His neoliberal image instead promoted the country's urban elites while marginalizing its rural regions. Assad failed to include Dar'awi representatives in his government, and members of Dar'a's tribal networks felt they were, as Haian Dukhan states, 'replaced by Alawites' (in Collins 2015). Dar'a's frustration with their lack of inclusion was exacerbated by Assad's poor handling of a drought that affected Dar`a in 2010. By the beginning of 2011, Wedeen (2013) notes, Syrian children had replaced the glamorously neoliberal first family in Dar'awi 
imaginings of Syria's future. Through circulated images of their arrest and evidence of torture, they began to 'offer up a vision of innocence and helplessness in the face of the professional managerial elite's consuming market-oriented excesses and the regime's overweening political power' (p. 873). Children became a uniting cause for the ensuing protests that spread north through Damascus and Aleppo.

The emergence of Dar`a as a space where Syria was being reimagined reiterates the importance of children's role in carrying out and carrying on this new kind of Syrianness. The Assad regime and its rival Dar`awi tribal families both understood well that childhood serves an important function in the regeneration of society because the formation of ideas of Syrianness occurs most influentially in this stage through schooling, child rearing, and local surroundings. Syrian identity is believed to be most malleable in children, who have not yet had enough experience to fully grasp its complexity, multifacetedness, and political weight. This point is subtly captured in the following story regarding the arrested children:

A popular account of subsequent events, repeatedly retold, describes the attempts by Dar`a MP Nasser al-Hariri to negotiate the children's release. Atif Najib, the local intelligence chief, responded to his efforts with contempt: he extended an insulting invitation to send Dar'a's women to his office so 'I can make them conceive some new kids'. (Leenders and Heydemann 2012, p. 147)

Lack of respect to women and the intimidation implied in the suggestion to 'conceive new kids' aside, this story has taken on various meanings and translations. For example, refugees took Najib's 'new kids' as a statement about creating subjects who would be loyal to the regime (Remnick 2013). An insult to Dar'a's men, whose allegedly disloyal children were useless to the regime and therefore disposable, as well as to Dar'awi women and children, these crude comments by Bashar al-Assad's cousin also reveal the state's priority to maintain the status quo by producing compliant rather than revolutionary citizens. While children have become a cause for the revolutionary struggle, they are equally important to the regime's project, for which loyal children guarantee another generation of regime survival. Dar'a's rejection of its expected responsibility to raise children loyal to the regime, fuelled by the ill-treatment of their children, became a major threat to Assad's government. As Assad's crackdown on protest and dissent in Dar'a reached a violent climax (the first of many) in 2012, Syrians from the city fled across the border to seek temporary refuge in Za'tari. The camp grew in size until it closed to new arrivals in 2015. Today, the population of Za'tari continues to reimagine Syria in its new space.

\section{Restoring childhood in the present}

There is general concern in the West that children's worlds are becoming limited to indoor play due to increasing parental concern of the dangers that the outside environment poses (Gill 2008). In a very different context, NGOs also believe that 'the domain of childhood is shrinking' (Ibid, p. 136) among camp-dwelling children who experience confinement to indoor play. Humanitarian NGOs operate with the understanding that a refugee camp is no place for children: it is fraught with a past trauma from living through a war as well as the abnormality of the current environment. The humanitarian project endeavours to restore childhood by re-introducing a sense of normality for children. 
In explaining his philosophy on humanitarian work in Za'tari, an aid worker made the following comments:

Kids at Save [the Children child-friendly centres] have an 'appropriate' childhood-I don't want to say 'normal' because what's normal to you isn't normal to them. But this is a safe place away from violence where trauma can be dealt with. And you know what? Actually you will notice that some children find the camp to be like a home because this is where they are building childhood memories. And their parents don't want to take that away from them. Every time I see children dancing or singing or laughing or playing at our centres, I see that they are building positive childhood memories. That's why when I am taking pictures, I don't like telling kids to look sad because if they are happy, let them be happy! (my emphasis throughout)

The aid worker's remarks reveal a humanitarian vocabulary that highlights this double issue of abnormality and security, acknowledged through his use of 'appropriate' over 'normal.' He alludes to the importance of place in childhood, making the camp feel like home through memory making, safety, and well-being. Furthermore, he mentions two building blocks, happiness and positivity, that can contribute to this sense of place and familiarity for children. The aid worker notes, however, that these efforts are limited to the child-friendly NGO centres throughout Za tari, named as such to differentiate these spaces from the rest of the camp, which is not a child-friendly environment. The centres provide havens, physically bounded by fencing and manned by a security guard, in which children can engage in appropriate interactions with other children, aid workers, and the material environment. These spaces are colourful, painted in the palette of the organization's logo, and often display small gardens. It is important to note that aid workers in the camp, the 'face of aid' (Arar 2017) for children, are a community of Jordanians and Syrians who speak the same language and share cultural sensitivities and often religion with the refugees. Interactions in the child-friendly centres nourish children's attachment to these spaces (Jack 2010) and contribute to the project of making the camp a home. In the following, I discuss how programming within the boundaries of child-friendly spaces attempts to restore aspects of a normative childhood through learning, socialization, and the cultivation of child agency.

\section{Learning}

There are sixteen schools, including three kindergartens, throughout the camp's twelve districts. For the children I worked with in Za tari, especially those who do not attend school, having a daily schedule that includes play, education, and skills development is paramount. Children actively seek out opportunities for purposeful activity and create daily routines that reconcile NGO programming with their other obligations. A thirteenyear-old discusses his daily schedule:

I wake up, eat breakfast with my family, and then I come here [to the NGO childfriendly centre] first thing. I play sports with my friends and participate in the activities. Then I go to work at noon to collect tomatoes on a farm. I love coming here. This is my favourite place, and then the football pitch.

A fifteen-year-old who daily attends NGO programming for girls mentioned that she participates in a game of football that fellow attendees organize every day in the centre's basketball court. An eleven-year-old explained that he plays in a child-friendly 
centre for boys every morning for a few hours, heads home for lunch, and makes it to the school gate by 11:45am before afternoon classes begin.

These examples, part of a myriad of similar stories echoed by many children in the NGO centres, reveal children's decisions to routinely participate in programming designed to offer a sense of regularity and regulation that would have been provided by schooling in Dar`a. The daily ritual of attendance mimics the temporal structuring of childhood by the educational system. Wyness points out the importance of a school schedule, which he argues 'acts as a kind of social and cultural map in that the rules and regulations regarding what children are able to do...ultimately conform to the temporal demands of the school day' (2000, p. 90). NGO formal and informal educational programmes encourage this kind of discipline and healthy activity through a structure of routine, conduct, and control over beneficiaries, imitating what pupils would expect from a school administration. Students of NGO-run education are provided with a similar sense of definitiveness, purpose, and objective as the pupils Wyness describes, who 'know where they are, what they are doing and when they are allowed to act' (Ibid). This regulation is in practice when boys wait their turn to play games, when girls use resources to create crafts within a specified time frame, and when kindergarteners observe the rules for safety and anti-bullying in their classrooms. Regulation in an abnormal environment of displacement and an 'ongoing state of emergency' (Martinez Mansell 2016) grants children not only a sense of security, but also predictability and control over their day-to-day lives.

Within the timetables of NGO programming, children have the opportunity to engage in skills training, where they learn life skills - and potentially employable services - such as sewing, barbering, photography, and electronic repair. A nineteenyear-old attends art therapy programming at a child-friendly centre, where she treats programming as training for her dream profession, photojournalism, and participates in a project called Inside Za 'tari, interviewing and taking pictures of children around the camp to be featured on Instagram. She proudly stated that her photos had won a prize during an art exhibition in the camp. One of her peers has his photographs of Za'tari credited by well-known newspapers, and other members of the group have established a magazine that runs stories on the camp for residents.

Programming in child-friendly centres also addresses emotions and attitudes in guiding children through physical development. For example, during a training session for Syrian and Jordanian volunteers, trainees discussed the difference in changes that boys and girls experience between the ages of twelve and seventeen. The aim of this exercise was to develop aid workers' understanding of the range of emotions, in some cases exacerbated by trauma (Olujic 1998, p. 323), that children may feel and to shape psychosocial programming around these needs. I observed this training during an activity in a child-friendly centre for boys in which children sitting around a circle discussed various emotions and identified ways to cope with them. The volunteers passed balloons around to each attendee to blow them up with air and then pop them to demonstrate how to alleviate negative feelings. These exercises reveal that educational NGO programming in Za tari addresses both aspects of displaced life that humanitarians deem abnormal for children as well as issues they consider to be normal physical development.

\section{Socialization}

Children in NGO programming learn to navigate life in displacement through social networks that form a sense of place (Williams 2006, p. 873). Relationships are formed and negotiated daily at the centres among children and between children and volunteers. 
Many children stated that they met their best friends at the centre they attend, where they learn to respectfully socialize with peers and to work through disagreements in a nonviolent manner. Attendance at the centres translates into expanded social circles for children who might otherwise interact only with family in the camp, replicating a feeling of social security many children feel they have lost since leaving behind friendships and other important social relationships in Syria. Social networking is a practice central to daily life in Dar`a. Participation at NGO centres allows children to develop a similar social fluency and to engage in the process of 'socialization' (Naisiko 2012 , p. 202) in which children obtain 'the knowledge, orientations and practices' that grant them social access to their community. Such social practice provides displaced children with the 'social and cultural continuity' (Baquedano-López in Naisiko 2012, p. 202) needed to progress into the social world of adults.

A key figure in the necessary development of social capacity among children at NGO centres is the aid worker. In addition to forming friendships, many of the children expressed having formed close mentorships with aid workers at the centres. Preparing to participate in the world of adult social circles can be challenging for children who have experienced trauma or lost a parent, not to mention the usual difficulties experienced during puberty. Mentorships offer role models for children who wish to seek guidance. In her study of a youth centre in Gambia, Naisiko (2012) observed that social support of adult figures was crucial for children struggling to cope with both physical and psychosocial issues. In Za`tari's child-friendly centres, mentorships respond to a similar need. They tend to be established on trust, as they provide stability, reliability, and advice for displaced children in a time of uncertainty, whether as refugees or as adolescents growing up and experiencing change.

One eighteen-year-old described his relationship with an aid worker who taught him barbering skills and enabled him to open his own barbershop in the camp, saying, 'I owe everything to him.' His development reveals how his close mentorship with this aid worker, especially in the absence of his father who is in Germany, has created the opportunity to become an entrepreneur. Owning a barbershop and building up a base of loyal customers has led to growing social capital for the young barber, which in this case also means much-needed financial capital. A sixteen-year-old expressed her close connection with an aid worker she relied on when in conflict with her parents, who were against her attendance at the centres because they believed her place as a woman was at home. This aid worker understood how to engage with the cultural beliefs held by the girl's parents while still advocating for her participation in women's empowerment programming. For this young refugee, the aid worker was a role model whose mentorship meant that she would be able to attend the centre the following day.

In Za tari, social capital that arises from these relationships is important for connecting children with employment in some cases, but also with cultural navigation skills and a respectable social standing among other community members. Friendships and mentorships are security blankets for children dealing with a variety of issues, whether psychosocial, physical, or cultural.

\section{Agency}

The act of creating a daily routine and regulating one's activities forms in children a sense of independence that is crucial to normative youth development. In displacement, humanitarianism treats children as dependent subjects, but at the same time, Za'tari's NGO programming instils in children a sense that they can exercise agency as independent beings in the camp. Navigating the resources, offered in a child's local environment, such as those discussed above, requires independent decision making and 
can make the space more meaningful to the child's development (Engwright in Jack 2010). Although child-friendly centres are under constant adult supervision, the spaces enable children to lead their own play and experiment with different activities without intrusion by teachers, parents, or other family members. Indeed, the space and time provided by such NGO centres allow children to negotiate relationships and form individual identities independent of parental assistance. For especially vulnerable children, including those without parents and those facing the possibility of child labour or early marriage, this independence means exercising agency and navigating circumstances over which they might otherwise have felt they had no control.

A twelve-year-old attendee of a child-friendly centre designated for boys lives in Za'tari without his parents, one of whom is in Germany and the other in Syria. When I first met him, his routine involved programming at the centre every morning followed by work transporting wheelbarrows of gravel to and from the camp in the afternoon. A month later, he decided to quit work in order to resume his education. Despite no longer engaging in child labour, he continued to attend the same NGO programming in the mornings. These decisions revealed his ability to create a new routine for himself, still revolving around NGO programming, but this time to make room for formal education. Such decisions, made primarily by children, demonstrate that they apply the skills, socialization, and independence that they practice in child-friendly centres to navigate the difficult terrain of displaced life in Za'tari.

\section{'Childhood Abnormalities': child labour and early marriage}

Because of difficult economic circumstances, often exacerbated by the absence of parental guidance or a parent's inability to work, it is not uncommon for some children to take on the responsibility to provide for their family at the expense of education or, as humanitarianism believes, their childhood. In Beehner's (2015) study on Za'tari's development, he notes that both refugees and humanitarians feel a troubling 'anythinggoes ethos' (p. 169) in the camp. As one refugee said to him, 'Everything is possible in Za tari.' The refugee was referring to the prevalence of early marriage (zawaj mubakkir), but this ethos could equally encompass other practices considered to be abnormalities of childhood in displacement, such as child labour ('amala). While NGO programming instils in children the skills discussed above, humanitarian efforts are nonetheless challenged by the persistence of child labour and early marriage. Indeed, the particular circumstances that constitute reality for children in Za tari necessitate that humanitarian management of childhood addresses the contradictions of the 'appropriate' childhood discussed by the aid worker cited at the beginning of this section. These contradictions put NGOs in an uncomfortable position as they struggle to find ways to decrease 'abnormal practices' while they create programmes to help child refugees cope with these same phenomena.

With child labour, NGOs attempt to enforce normality by discouraging children from working, but they also understand that labour is an unfortunate necessity for some children who need to afford provisions in order to continue a sense of a normal life. The entrance to Za tari is often busy with children leaning on wheelbarrows awaiting work from outside contractors. Other children head to nearby tomato and olive farms, where conditions are often exploitative, as one thirteen-year-old said, 'They didn't give me my wages last time because I took a break to drink water.' Humanitarians approach the issue of child labour through the skills training mentioned above by providing safer alternatives to physically intense child labour, such as barbering and electronic repair. Some NGOs provide programming for boys engaged in labour in order to be able to have time for play. On leaving the camp for the day, one aid worker recognized one of 
his programme attendees waiting at the entrance with a wheelbarrow. He said to him: 'You told me you were working only until 3 pm today! Please go home and rest.' While sympathetic, of course, these are awkward responses to child labour that do more to treat the symptoms than the cause. Aid workers do not like to advertise that child labour exists in a humanitarian space whilst they are aware of it.

Perhaps more difficult for humanitarians to concede is early marriage. Just as underage boys often take on a financial burden by working, underage girls in Za tari are increasingly forced into marriage to relieve their families monetarily and to generate extra income through their dowry (UN Women 2013). While early marriage is customary in Dar`awi culture for fourteen to eighteen year olds, marrying significantly older Jordanian men is not. As parents in the camp become increasingly desperate to maintain what they believe is the honour of their daughters while living in displacement, early marriage has become more prevalent: 'You can propose to my daughter or any girl [in Za 'tari], and you will marry her very fast,' a camp resident remarked to Beehner in a conversation about the situation of marriage for Za'tari's underage girls (2015, p. 169). Parents' consolation comes in thinking that their daughters will be protected by marriage to an older Jordanian man and will live 'like any normal girl' (zay ay bint tabi 'iyya), as one young divorcee quoted her parents' argument to convince her to accept marriage the year before. For these parents, life for their children outside the camp is more dignified, even if it is through the means of early marriage.

An attendee at a child-friendly centre for girls was able to obtain a divorce after being unwillingly married to a twenty-four-year-old Jordanian man. At sixteen, she returned to programming at the centre where she chose to surround herself with peers her age. An aid worker commented on her story, 'After all, she is just a child,' a reminder meant to convey a perceived need to reinstate an appropriate childhood for a girl who supposedly lost it when she became a child bride. In order to combat early marriage, NGOs attempt to teach women's rights to girls in their child-friendly centres. A celebration held during International Women's Day included a video explaining women's rights and how women should be treated in their marriage. There were choreographed dance performances, speeches, and team building exercises. The participants involved were women of all ages, including many engaged under-aged girls. Many women enthusiastically participated in the Women's Day activities. One participant appreciated that it was a 'special day because it is just for us women'. But it is less clear how much of women's lives at home will change because of these activities. NGO programming can inspire girls to pursue education instead of marriage, but it cannot prevent parents from making the final decision.

The unintended outcome of NGO responses to child labour and early marriage is the normalizing of extra-ordinary circumstances for children in Za tari. Humanitarians find themselves trying to schedule 'time for childhood' for boys engaged in child labour and to teach women's rights to engaged under-aged girls. Nevertheless, it must also be acknowledged that children actively navigate these exceptional circumstances and engage in adapting humanitarian cultivated childhoods to their unique situations. The significance of these 'restored' childhoods, thus, is not humanitarian success in maintaining an environment completely free of child labour and early marriage, but in promoting skills that children learn to use to confront such threats to an appropriate childhood.

To be sure, these new childhoods are not a return to pre-war Syrian childhoods, nor do they claim to be, as implied in the aforementioned word-choice of 'appropriate' over 'normal.' NGO involvement in the management of camp childhoods inherently 
shapes childhoods that are different from what they might have been in a peaceful Syria. For instance, children are introduced to new forms of play, such as the British sport of rugby or the Brazilian martial art of capoeira, as well as to new ideas, including women's rights. One child participating in a rugby match explained that the sport was completely new to him and his friends, but they quickly grew to love it because 'it's fun and easy and it makes us happy.' Children come to NGO programming with their knowledge of Syrian traditions and community beliefs but also open to new ideas and activities. The outcome of this is a hybrid experience; not a completely Syrian childhood nor a completely humanitarian one.

\section{Childhood for the future}

The importance of placemaking and social networking for children in Za tari is that it enables them to identify with a greater community. Navigating the space of the camp grants them a certain ownership over it and allows them to act as social and political agents. This independence means children can experiment with their identity and reclaim a sense of belonging in displacement (Jack 2010). However, NGO programming does not aim to nurture social, cultural, or political identities in children for their time in displacement. Rather, as Hoffman notes, it intends to prepare children for the "day after" of their humanitarian present' (2017, p. 101). The humanitarian regime in a refugee camp is meant to create citizens for a later time, space, and society (Fresia and Von Känel 2015, Turner 2014); in this case, for children's future in Syria. Agency, education, and social networking skills are not meant to empower a displaced population in Jordan but to pay off upon return to Syria, when children can begin once again to contribute to society in a tangible and meaningful way. Even positive memory making, a main building block of restoring a happy childhood, can only be enjoyed from a future time and space, as Syrian adults looking back on their youth. Such efforts by the humanitarian regime in Za tari, while problematic and increasingly unrealistic in protracted displacement, aim to shape childhoods for the future.

In dealing with children's pasts in Syria, NGOs in the camp engage in children's political histories only in the context of discussing the future. A question posed countless times by aid workers to children in Za'tari was, 'What's your dream?' [Shu hilmak(ik)?], to which children would provide the expected response: 'To return to Syria.' This 'dream', more symbolic than specific, is encouraged by aid workers. Exchanges centred on the premise of return occurred frequently within child-friendly centres. For example, World Vision, a religious-based organization focusing on children, published a story on Syrian refugee children in Lebanon titled 'Childhood Lost and Found', in which the supervisor of a child-friendly centre is quoted: 'We don't ask about the things that trouble them. We are here to support and encourage them' (Reid 2016). In this story, World Vision similarly believes that the restoration of childhood is founded on positivity and a forward outlook. But in avoiding talking with children about their pasts in an attempt to maintain political neutrality, this depoliticization of displaced children's pasts works to objectify the refugee as a cultureless 'object of compassion' (Feldman 2012, p. 155). This is not to say that children in Za' tari do not dream of returning to Syria, but that their complex histories and relations with their homeland and home cities are overlooked and simplified.

Despite the humanitarian apparatus's mission for children to forget their past as they prepare to eventually resurrect as ideal citizens of a future - apolitical - Syria, the reality is that this future is shaped by a past from which Za'tari's children cannot escape. It must be acknowledged that while humanitarianism can be a limiting force, 
camp children learn how to operate under these restrictions. Even within the parameters of this politics of time, interactions between NGOs and children in child-friendly spaces set conditions for future possibilities that children can choose to pursue on their own.

\section{Remembering the past}

NGO programming encourages children to focus on a depoliticised future divorced from the political struggles that brought them to the camp. Za' tari's governance attempts to ignore the fact that the overwhelming majority of camp residents fled from the city that prompted the revolution. It has discouraged political activity like the uncontrollable anti-regime demonstrations that occurred in the camp regularly during Za`tari's first years (Tanglao 2014, Kadri and Rudoren 2013, Al Jazeera 2012). At the same time, Dar'awi camp children grow up understanding the importance of their origins at home and cannot ignore their own political histories that tie them to their home city. While humanitarianism narrows children's focus on a future premised on the return to Syria, these children exist in an apparatus where they learn to define the contents of this focus through the skills discussed in the previous section. Children in Za tari operate on an adjacent politics of time, remembering their past in their goals for the future as they presently redefine what it is to be a Dar`awi Syrian.

Considering Za'tari to be a neutral apolitical space, as humanitarian space ideally should be (Audet 2015, Weiss and Barnett 2008), neglects the fact that the camp is shaped by residents' idea of Syria and a communal desire to return to it. Whether or not a child actually remembers Syria, life in Za tari equates to knowing a particular version of Syria through daily activity outside of NGO space. Children pass shops in the market with names like Dar`a al-Balad lil-Khiyata (Dar`a al-Balad Tailor), Mat`am Dimash (Damascus Restaurant), and Mat'am al- 'Awda (Restaurant of Return). They know artists who have recreated miniature versions of Syrian landmarks in a caravan workshop (Dunmore 2016a). They walk in streets named after streets in Syria. They observe the customs of refugees from other parts of Syria (Dalal 2017). They observe discussions at home among relatives who follow the unfolding events in Dar'a. But children also continuously reimagine Syria with new ideas because of their unique experiences in displacement.

NGO programming that aims to restore childhood leads children in Za`tari to customize humanitarian production of childhood to their needs and desires. They learn to discuss Syria in an abstract and idealistic manner in NGO spaces, while also maintaining political identities as revolutionaries and identifying with a concrete home; when asked where one is from, each child proudly responded with his or her home city within the greater Dar`awi region-Dar`a, Dar`a al-Balad, Taybeh, Izraa, or Ibtaa were among the most common. These home cities represent for children a more meaningful return, one that carries with it specific places, people, and times. Children keep daily reminders of home in the form of small Syrian revolution flags or drawings of home or by tending to gardens that emulate Dar'a's lush environment. Maintaining their identification with Dar'a connects children to the space where a new version of Syria was imagined in opposition to the one crafted by the regime. In this way, asserting a Dar`awi origin over a more general Syrian one in a refugee camp in Jordan continues this political struggle.

At the same time, children craft new identities as displaced Syrians growing up in a camp in Jordan, but these new experiences never contradict or undermine their Syrianness. While NGOs push an apolitical Syrian identity expression through a focus on a general idea of return, children explore, reclaim, and create personal Syrian camp identities. The refugee camp becomes a 'hybrid organism, not reproducing any socio- 
spatial form that already exists' (Agier 2011, p. 53), shaping and being shaped by this experimentation of new identities. In Za tari, more than a simple Syrian identity is being manifest as a complex web of Syrianness-Dar'awi, Dimashqi, Shami-is being continuously defined, redefined, and negotiated under the shadow of the limiting humanitarian presence.

\section{Dreams for the future}

Humanitarian emphasis on rebuilding Syria combined with already fervent Syrian pride among Za'tari's residents gives children a renewed purpose for the meantime. Children are taught that in order to make an impact upon return to Syria, they can use the present time and space as preparation. Many children explained that before attending NGO programming, they were 'just sitting around' until they could return home. As time passed and they discovered child-friendly centres, they described a renewed ability to think about the future, which had been put on hold.

Having dreams for the future is another integral aspect to childhood development. Especially for children in displacement, the ability to plan or work toward a future implies that there will be one. Brun (2016) argues that the humanitarian system must define futures beyond the temporary emergency state of the refugee camp to provide meaning to the present beyond day-to-day survival for the displaced. A recent study on resilience among Jordanian and displaced Syrian youth living in urban areas of Jordan found that dreams and ambitions were a main source of resilience among young Syrian refugees especially (Panter-Brick et al, 2017).

Beyond mere return, one thread evident in dreams expressed by children in Za tari was the desire to pursue a career in service to fellow Syrians. Professions such as doctor, journalist, farmer, craftswoman, engineer, and architect were mentioned with frequency. These careers are active positions that create, solve, and repair. Children's dreams were also often responsive to personal issues they had experienced: a sixteenyear-old divorcee discussed her dream of becoming a women's rights advocate for her Syrian peers, a thirteen-year-old who has been deprived of an education aspired to become a maths teacher in Syria, and a fifteen-year-old with sustained leg injuries dreamed of being a surgeon.

The importance of dreams is that they allow children to respond positively and productively to displacement by using this protracted situation as a time to train and prepare for a future. In the middle of the Jordanian desert, dreams are one way for children to reach beyond the camp and conceive of a time when their life in a refugee camp is in their past. In this way, it is a mistake to underestimate potential without opportunity. The significance of dream building and placemaking lies in the fact that children in NGO programming learn that being in a camp and having a future are not mutually exclusive. As a thirteen-year-old stated in a short film by UNHCR, 'The camp is not the worst thing; it's worse to not have a future' (Dunmore 2016b). By encouraging dreams and goals for children, even if for a future time, humanitarians at least give children something positive and meaningful to work toward. Though undermined by the indefiniteness of the humanitarian condition, this opportunity is valued by children whose outlook on life has improved because of these dreams.

\section{Conclusion}

This article has explored how NGO attempts to restore a sense of normality for children in Za tari have resulted in a generation of Syrian children who are living very particular childhoods in the present and learning to work toward very particular futures. 
Children's engagement with aid workers takes place within spaces that promote education, socialization skills, and independence in an attempt to restore an appropriate childhood. They build their daily routines around NGO programming and adapt the intangible benefits to their individual situations. While NGOs do not encourage children to talk about their political histories, children respond to their pasts by cultivating dreams and preparing for the future. From these negotiations and navigations of childhoods in a challenging environment, children shape a particular Syrian culture in the camp that insists on the return to their home cities while simultaneously cultivating new identities shaped by their daily lives in Za'tari.

In daily conversation with children in Za'tari, they displayed an overwhelming determination to make something of their lives that was inspirational at the very least. It seemed that Syrian children in the camp continue to represent a link between a peaceful Syrian past and a hopeful Syrian future, a connection encouraged by Za'tari's humanitarian governance. But at what point is this hope mere idealism, a tool of humanitarianism operating under state projects to prevent refugees from integrating?

The optimism I encountered among children in the camp was reassuring. Still, we must ask, what kind of future is being made available for these children if near future return to Syria is not realistic? How can humanitarians turn dreams into plans? How can children become doctors, journalists, teachers, and engineers if they are not considered a part of society? Humanitarianism has an obligation to figure out how to promote a future that children can actually achieve even if return is not granted anytime soon. We must push for solutions, lest the potential without opportunity becomes merely a performance, a patronizing attempt to keep refugees busy in order to distract them from the fact that humanitarianism has failed them.

\section{Acknowledgements}

I would like to give a special thank you to Shahla and Randa Suleiman, without whom my fieldwork would not have been possible. I am indebted to Save the Children Jordan and its dedicated Media and Communications team for making room for me. I am also grateful for the support of my advisor, Dr Paul Anderson. Finally, I thank the community of Za`tari refugee camp for their hospitality and openness, and especially the children who immediately accepted me in their lives and whose stories greatly influenced this article.

Written: 3 April 2017. Resubmitted: 31 July 2017, 23 August 2017.

\section{References}

Agier, M., 2011. Managing the undesirables: refugee camps and humanitarian government. Trans. David Fernbach. Polity Press: Cambridge.

Akesson, B., 2014. Castle and cage: Meanings of home for Palestinian children and families. Global Social Welfare, 1, 81-95.

Al Jazeera, 2012. Protest rocks Jordan refugee camp, September 25. Available from: http://www.aljazeera.com/news/middleeast/2012/09/2012925113236322283.htm 1 (Accessed 3 Jun 2016).

Arar, R., 2017. Bearing witness to the refugee crisis: western audiences and Jordanian humanitarian workers. Middle East Institute. Available from: http://www.mei.edu/content/map/bearing-witness-refugee-crisis (Accessed 24 Feb 2017). 
Audet, F., 2015. Humanitarian space. In: J. Peterson and R. MacGinty, eds. The Routledge companion to humanitarian action. Routledge Companions. Abingdon, Oxon: Routledge.

Beehner, L., 2015. Are Syria's do-it-yourself refugees outliers or examples of a new norm?. Journal of International Affairs, 68 (2), 157-175.

Brun, C., 2016. There is no future in humanitarianism: emergency, temporality and protracted displacement. History and Anthropology, 27 (4), 393-410.

Collins, D., 2015. Tribal 'blood ties' and Syria's civil war: Q\&A. December 11. Available from: http://www.syriadeeply.org/articles/2015/12/9039/tribal-bloodties-syrias-civil-war-qa/ (Accessed 13 Jan 2016).

Connolly, M., Ennew, J., 1996. Children out of place: introduction. Childhood, 3, 131145.

Dalal, A., 2017. Uncovering culture and identity in refugee camps. Humanities, 6 (61).

Dunmore, C., 2016a. Syria's landmarks restored in miniature. UNHCR Tracks, January 5. Available from: http://tracks.unhcr.org/2016/01/syrias-landmarks-restored-inminiature/ (Accessed 4 Feb 2016).

, 2016b. Syrian wrestling champ inspires young refugee's dreams. UNHCR, July 26. Available from:

http://www.unhcr.org/uk/news/stories/2016/7/5795e5cc4/syrian-wrestlingchamp-inspires-young-refugees-dreams.html (Accessed 27 Jul 2016).

Feldman, I., 2008. Mercy trains and ration rolls: between government and humanitarianism in Gaza. In: I.M. Okkenhaug and N. Naguib, eds. Interpreting welfare and relief in the Middle East. Leiden: Brill, 175-194. , 2012. The humanitarian condition: Palestinian refugees and the politics of living. Humanity, 3 (2),155-172. , 2015. Looking for humanitarian purpose: endurance and the value of lives in a Palestinian refugee camp. Public Culture, 27 (3), 427-447.

Fernea, E., 1995. Childhood in the Muslim Middle East. In: E. Fernea, ed. Children in the Muslim Middle East. Austin: University of Texas Press, 3-16.

Fresia, M., von Känel, A., 2015. Beyond space of exception? Reflections on the camp through the prism of refugee schools. Journal of Refugee Studies, 29 (2), 250272.

Gill, T., 2008. Space-oriented children's policy: creating child-friendly communities to improve children's well-being. Children and Society, 22, 136-142.

Hoffman, S., 2017. Humanitarian security in Jordan's Azraq Camp. Security Dialogue, $48(2), 97-112$.

Jack, G., 2010. Place matters: the significance of place attachments for children's wellbeing. British Journal of Social Work, 40, 755-771.

Jansen, S., 2014. On not moving well enough: temporal reasoning in Sarajevo yearnings for 'normal lives'. Current Anthropology, 55 (9), S74-S84.

Kadri, R., Rudoren, J., 2013. Tensions high after riot at Syrian refugee camp in Jordan." The New York Times, April 20, sec. Middle East. Available from: https://www.nytimes.com/2013/04/21/world/middleeast/tensions-high-after-riotat-syrian-refugee-camp-in-jordan.html (Accessed 3 Jun 2016).

Kelly, T., 2008. The attractions of accountancy: Living an ordinary life during the second Palestinian intifada. Ethnography, 9 (3), 351-376.

Leenders, R., 2013. 'Oh Buthaina, oh Sha'ban-the Hawrani is not hungry, we want freedom!': revolutionary framing and mobilization at the onset of the Syrian uprising. In: J. Beinin and F. Vairel, eds. Social movements, mobilization, and 
contestation in the Middle East and North Africa. Stanford University Press, Stanford, 246-261.

Leenders, R., Heydemann, S., 2012. Popular mobilization in Syria: opportunity and threat, and the social networks of the early risers. Mediterranean Politics, 17 (2), $139-159$.

Martinez Mansell, C., 2016. How to navigate a refugee camp. Places Journal. Available from: https://placesjournal.org/article/camp-code/ (Accessed 1 May 2016).

Naisiko, T., 2012. The value of socialization in negotiating livelihoods among the youth: a case of Bugembe youth group in Uganda. In: Negotiating the livelihoods of children and youth in Africa. CODESRIA, Dakar.

Navaro-Yashin, Y., 2003. 'Life is dead here': sensing the political in no-man's land. Anthropological Theory, 3 (1), 107-125.

Olujic, M., 1998. Children in Extremely Difficult Circumstances: war and its aftermath in Croatia. In: N. Scheper-Hughes and C. Sargent, eds. Small wars: The cultural politics of childhood. University of California Press: Berkeley, 318330.

Panter-Brick, C., Dajani, R., Ager A., Hadfield, K., Eggerman, M., and Ungar, M., 2017. Resilience in context: a brief and culturally grounded measure for Syrian refugee and Jordanian host-community adolescents." Child Development, 0 (0), $1-18$.

Poretti, M., Hanson, K., Darbellay, F., Berchtold, A., 2014. The rise and fall of icons of 'stolen childhood' since the adoption of the UN Convention on the Rights of the Child. Childhood, 2 (1), 22-38.

Quaretta, E., 2016. Batoto wa Maria: humanitarianism, the provincial state, Salesian missionaries and the concept of childhood in the Democratic Republic of Congo (DRC). In: A. De Lauri, ed. The Politics of humanitarianism: Power, ideology and aid. I.B. Tauris: London, 99-124.

Reid, K., 2016. Childhood lost and found. World Vision Magazine, June 21. http://magazine.worldvision.org/stories/syrian-refugees-childhood-lost-andfound (Accessed $2 \mathrm{Jul}$ 2016).

Remnick, D., 2013. City of the lost. The New Yorker, August 26. Available from: http://www.newyorker.com/magazine/2013/08/26/city-of-the-lost (Accessed 2 May 2016).

Suski, L., 2009. Children, suffering, and the humanitarian appeal. In: R.A. Wilson and R.D. Brown, eds. Humanitarianism and suffering. Cambridge University Press: Cambridge.

Tanglao, L., 2014. Deadly violent clashes hit Jordan's Zaatari Syrian Refugee Camp. VICE News, April 7. Available from: https://news.vice.com/article/deadlyviolent-clashes-hit-jordans-zaatari-syrian-refugee-camp (Accessed 3 Jun 2016).

Turner, S., 2014. Making good citizens from bad life in post-genocide Rwanda. Development and Change, 45 (3), 415-434.

- 2015. What is a refugee camp? Explorations of the limits and effects of the camp. Journal of Refugee Studies, 29 (2): 139-148.

UNHCR Syria Regional Refugee Response. UNHCR. Available from: http://data.unhcr.org/syrianrefugees/settlement.php?id=176\&country=107\&regi on=77 (Accessed 1 Apr 2017).

Children in Especially Difficult Circumstances [online]. UNICEF: Office of Research Innocenti. Available from: https://www.unicefirc.org/php/Thesaurus/Thesaurus_Res.php?THES_ID=317\&THES_LANG=1\& THES_SERCH=3 (Accessed 31 Jul 2016). 
Wedeen, L., 2013. Ideology and humor in dark times: notes from Syria. Critical Inquiry, 39.

Weiss, T., Barnett, M., 2008. Humanitarianism in question: Politics,power, ethics. Cornell University Press: Ithaca.

Williams, L., 2006. Social networks of refugees in the United Kingdom: tradition, tactics and new community spaces. Journal of Ethnic and Migration Studies, 32 (5), 865-879.

Wyness, M., 2000. Contesting childhood. Falmer Press: London. 